\title{
Células madre en odontología: realidad o ilusión
}

\section{Stem cells in dentistry: reality or illusion}

Sobre las células madre se investiga y se seguirá investigando, es la ilusión que la humanidad espera para reparar y recomponer algunos órganos que presentan patologías por diversas causas.

Este tema ha despertado tanta expectativa que es imposible no hablar de ella en los foros científicos. En algunos campos ya hay resultados alentadores, como por ejemplo en el tratamiento de enfermedades hereditarias, cáncer, enfermedades cardíacas, mal de Parkinson, artritis reumatoide, diabetes de tipo 1, etc. Sin embargo, en otros, todavía hay mucho por trabajar.

Los científicos utilizan las células madre de los embriones obtenidos por fertilización in vitro. Un hecho trascendente es que las células madre embrionarias tienen capacidad para convertirse en cualquier tipo de célula, lo que representa un desafío para los investigadores (1).

Así, la odontología es una de las áreas donde se ha reportado que la pulpa de piezas dentarias primarias son potenciales donadoras de células madre y han contribuido a solucionar patologías de otros órganos del organismo. Sin embargo, todavía no hay rastros para sustituir piezas dentarias perdidas. Se ha avanzado poco en éste aspecto, pero hay la ilusión y esperanza que sí se pueden conseguir resultados alentadores en el tiempo.

"Las células madre de la cavidad bucal son células que poseen un potencial de multidiferenciación y por tanto pertenecen al grupo de células madre adultas con la capacidad para formar células con carácter osteoodontogénico, adipogénico y neurogénico"(2).

Betancourt y col. (2) han dedicado especial atención al estudio de células madre de la cavidad bucal, identificando cuatro grupos: a) Células madre en pulpa de dientes primarios, b) Células madre en pulpa de dientes permanentes, c) Células madre presentes en espacios periodontales y d) Células madre de la mucosa bucal. Estas células tienen a -criterio de los autores- potencial aplicación clínica en el aparato masticatorio en la regeneración de tejido óseo, dentina, ligamento periodontal y de dientes.

Células madre han sido obtenidas de la médula ósea de la cresta ilíaca de pacientes y colocadas en defectos periodontales, observándose reducción de las furcaciones de primer grado, lo cual indicaba un mejoramiento de los defectos en relación al valor inicial (3).

Pérez y col. (4) reportan el caso de un paciente con encía que presentaba signos de inflamación crónica generalizada, migración y movilidad dentaria grado II y III en incisivos y molares, bolsas periodontales profundas generalizadas $(4-8 \mathrm{~mm})$ y lesiones de furca grado III; notándose, después de 6 meses de aplicación de células 
madre, lo siguiente: la encía retornó a sus características de normalidad, hubo disminución de la movilidad dentaria en los sectores tratados, se observó disminución del número de bolsas y las que se mantuvieron disminuyeron su profundidad a $3 \mathrm{~mm}$, y en la radiografía de evolución se apreció aumento de la densidad ósea.

Fuentes-Ayala y col. (5) reportaron el caso de un paciente masculino de 27 años de edad, con defectos óseos provocados por la enfermedad periodontal, al que le implantaron células madre hematopoyéticas adultas autólogas, a los 12 meses se observó hueso neoformado y aumento de la densidad ósea, los resultados obtenidos con la técnica de colgajo más implantación celular fueron satisfactorios.

Así también, Torres y col. (6) reportaron el caso de un paciente portador de un quiste dentígero mandibular con gran destrucción ósea, donde se colocó células madres adultas, identificando que éstas indujeron la regeneración ósea en las cavidades quísticas de los maxilares.

A pesar de estos estudios preliminares y alentadores de la especialidad, todavía hay mucho camino por recorrer y mucha investigación por realizar. En nuestro país, la legislación peruana aún no está preparada para este gran reto. Seguirán todavía por un tiempo las controversias en la investigación de este tema. Pero hay que seguir investigando porque estamos convencidos que los resultados serán fructíferos en el futuro.

Fredy Gutiérrez-Ventura ${ }^{1, a, b}$

\section{REFERENCIAS BIBLIOGRAFICAS.}

1. Castagnino JM. Células madre embrionarias. Acta Bioquímica Clínica Latinoam. 2005; 39(3):277-8.

2. Betancourt K, Barciela J, Guerra J, Cabrera N. Uso de células madre en el complejo bucofacial. Rev Arch Méd Camagüey. 2012; 16(5):651-61.

3. Carini F, Menchini GB, Biagi E, Salvade' A, Sbordone L, Baldoni MG. Estudio experimental sobre la utilización de células madre humanas en la terapia de los defectos periodontales: resultados preliminares. Av Periodon Implantol. 2011; 23(2):97-107.
4. Pérez A, Domínguez L, Ilisástigui ZT, Hernández P. Utilización de células madre en el tratamiento de defectos óseos periodontales. Rev Cubana Estomatol. 2009; 46(4):122-8.

5. Fuentes-Ayala E, Lourido-Pérez $H$ de la C, LeónAmado L, Quintero-Pérez W, Fleitas-Vigoa D, PérezHernández LY. Uso terapéutico de células madre adultas en enfermedad periodontal. Rev Cubana Hematol Inmunol Hemoter. 2013; 29(4):419-25.

6. Torres LE, Marimón ME, Morejón FC, Camacho R, León L. Autotrasplante de células madre adultas en defecto óseo de rama mandibular por quiste dentígero. Rev Cienc Médicas. 2011; 15(4):89-101. 